Tersedia online di: http://ejournal-balitbang.kkp.go.id/index.php/jkpi
e-mail:jkpi.puslitbangkan@ gmail.com
JURNAL KEBIJAKANPERIKANANINDONESIA
Volume 11 Nomor 1 Mei 2019
p-ISSN: 1979-6366
e-ISSN: 2502-6550
Nomor Akreditasi Kementerian RISTEKDIKTI: 21/E/KPT/2018

\title{
PENGELOLAAN PERIKANAN RAJUNGAN (Portunus pelagicus) BERDASARKAN ANALISIS SPASIAL DAN TEMPORAL BIOEKONOMI DI PERAIRAN PESISIR TIMUR LAMPUNG
}

\section{MANAGEMENT OF BLUE SWIMMING CRAB (Portunus pelagicus) FISHERIES BASED ON SPATIAL AND TEMPORAL ANALYSIS OF BIOECONOMIC IN THE EASTERN COAST OF LAMPUNG}

\author{
Aprillia Kartika Ekawati*1, Luky Adrianto ${ }^{1,2}$ dan Zairion ${ }^{1,2}$ \\ ${ }^{1}$ Fakultas Perikanan dan IImu Kelautan, Institut Pertanian Bogor, Jl. Agatis, Kampus IPB Dramaga, Bogor, 16680-Indonesia \\ ${ }^{2}$ Pusat Kajian Sumberdaya Pesisir dan Lautan, Institut Pertanian Bogor, Kampus IPB Baranangsiang, Jl. Raya Pajajaran No.1, \\ Bogor-16127, Indonesia \\ Teregistrasi I tanggal: 14 Februari 2019; Diterima setelah perbaikan tanggal: 20 September 2019;
} Disetujui terbit tanggal: 01 Oktober 2019

\begin{abstract}
ABSTRAK
Pesisir timur Lampung merupakan salah satu daerah penghasil rajungan di Indonesia. Jumlah hasil tangkapan yang rendah menghasilkan keuntungan yang rendah pada setiap upaya penangkapan. Tujuan dari penelitian ini adalah untuk menganalisis nilai aktivitas perikanan rajungan dalam bentuk trip optimal dan keuntungan untuk pengelolaan perikanan rajungan di pesisir timur Lampung. Pengumpulan data dilakukan dengan menggunakan metode purposive sampling. Karakteristik aktivitas penangkapan rajungan didapatkan jumlah kapal (40-250 unit) dan jumlah hari melaut (16-27 trip/bulan) pada setiap lokasi. Nilai produksi pada musim puncak di pendaratan rajungan Way Seputih dan Sungai Burung lebih tinggi dibandingkan 3 lokasi lainnya. Jumlah alokasi spasial tertinggi pada musim puncak di S1 adalah di Sungai Burung dengan jumlah 1974 trip/ musim dan di strata 2 tertinggi di Kuala Penet dengan jumlah 2763 trip/musim. Musim sedang di S1 dan S2 tertinggi di Way Seputih 3540 trip/musim, dan Labuhan Maringgai 2883 trip/musim. Musim paceklik S1 dan S2 Sungai Burung 10088 trip/musim dan Kuala Penet 4708 trip/musim. Penetapan alokasi upaya penangkapan (trip/musim) dapat dijadikan acuan pembatasan upaya penangkapan rajungan pada setiap stratifikasi di 5 lokasi pendaratan rajungan.
\end{abstract}

Kata Kunci: Alokasi spasial; hasil tangkapan; trip optimal; keuntungan

\begin{abstract}
The eastern coast of Lampung is one of the blue swimming crabs (Portunus pelagicus) wild catch producing areas in Indonesia. Low catch weight causes a small profit to be gained on each fishing effort. Spatial allocation in fisheries seen from the location or distance and costs of activities. The purpose of this study was to analyze the value of BSC fishing activities in the form of optimal trips and benefits for the management of BSC fisheries on the east coast of Lampung. Data collection is done using purposive sampling method. Characteristics of BSC fishing activities obtained the number of ships (40-250 units) and number of days of fishing (16-27 trip/month) at each location. The production value in the peak season at the Way Seputih and Sungai Burung landings had a higher number compared to the catch per-trip in 3 other locations. The highest spatial allocation value in the peak season at S1 in the Sungai Burung with 1974 trips/season and the highest 2 in Kuala Penet with 2763 trips/season. The highest season in S1 and S2 is highest in Way Seputih 3540 trips/season, and Labuhan Maringgai is 2883 trips/season. Famine season in S1 and S2 is highest in Sungai Burung as many 10088 trips/season and Kuala Penet 4708 trips/season. Determination of alocation for fishing effort (trip/season) can be used as a reference for limiting the effort to catch of BSC in each stratification in 5 crab landing sites.
\end{abstract}

Keywords: Catch; optimal trip; profit; spatial allocation

Korespondensi penulis:

e-mail: aprilliaekawati@gmail.com

Telp.+62 899-8903-118 


\section{PENDAHULUAN}

Rajungan (Portunus pelagicus) merupakan salah satu sumberdaya perikanan yang bernilai ekonomis penting. Volume ekspor rajungan Indonesia tahun 2018 mencapai 21577,3037 ton dengan nilai ekspor mencapai US\$ 370 juta (KKP, 2018). Tingginya nilai ekonomi menyebabkan meningkatnya aktivitas penangkapan di alam (Setiyowati, 2016). Selain itu pengusahaan perikanan rajungan yang bersifat open acess seperti pada perikanan lainnya menyebabkan makin tingginya upaya penangkapan (effort) dan menyebabkan daerah penangkapan yang lebih jauh dari biasanya (Adam et al., 2006).

Eksploitasi yang tinggi pada rajungan akan menyebabkan terjadinya penurunan stok dan mengganggu aktivitas pemanfaatan dalam menunjang perekonomian nelayan serta sektor perikanan dan kelautan (Kurnia et al., 2014). Hubungan antara ekologi dan ekonomi dapat menunjukan bahwa sumber daya alam digunakan sebagai model stok alam dalam ekonomi. Hal tersebut menurut Damora, (2016) dapat memberikan informasi tentang kondisi stok serta menjaga keberlanjutan stok. Perikanan tangkap, seperti sektor ekonomi lainnya merupakan salah satu aktivitas yang memberikan kontribusi terhadap kesejahteraan di wilayah setempat. Upaya mencapai manfaat nilai guna yang maksimal dalam jangka panjang dapat dilakukan apabila sumberdaya perikanan dapat dialokasikan secara optimal (Supriani, 2007).

Alokasi spasial pada perikanan dilihat dari lokasi atau jarak dan biaya yang dikeluarkan untuk penangkapan ikan untuk mendapatkan target penangkapan. Alokasi spasial pada intensitas perikanan tangkap pada beberapa alternatif daerah penangkapan ikan adalah fungsi dari peluang menemukan target tangkapan. Distribusi stok yang tersebar secara spasial dan kondisi lingkungan pada aspek spasial diperhitungkan meskipun pada jarak yang sempit (Anderson \& Seijo, 2010).

Informasi hubungan ekologi dan ekonomi pada pengelolaan sumberdaya alam digunakan sebagai model stok alam dalam ekonomi, dimana pengelolaan sumberdaya perikanan tidak hanya memberikan informasi tentang kondisi stok sumberdaya, tetapi juga memberikan informasi bagaimana mengelola sumberdaya tersebut dan juga pertumbuhan ekonomi nelayan (Damora, 2016). Kajian terkait spasial dan temporal struktur stok, dan pola eksploitasi rajungan telah dilaksanakan di perairan pesisir Lampung Timur. Rataan kelimpahan dari setiap lokasi penangkapan berbeda nyata berdasarkan waktu pengamatan namun tidak berbeda nyata menurut stratifikasi area. Sedangkan rataan biomassa berbeda nyata menurut stratifikasi area dan waktu pengamatan (Zairion, 2015). Informasi sebaran spasial dan temporal sumber daya perikanan rajungan diperlukan sebagai dasar pengelolaan menurut nilai produksi rajungan pada setiap lokasi penangkapan.

Kajian bioekonomi spasial dan temporal pada perikanan rajungan didasari karena kurang tepatnya metode bioekonomi secara konvensional jika diterapkan pada perikanan rajungan (perikanan demersal) yang memiliki ciri terdapatnya distribusi stok. Karakteristik ekologi dan ekonomi yang dilakukan pada analisis bioekonomi spasial bertujuan untuk mendapatkan model optimasi dalam pemanfaatan sumber daya di suatu lokasi, meliputi nilai alokasi spasial dan total keuntungan ekonomi secara kumulatif (Damora, 2016). Penelitian analisis bioekonomi secara spasial pada suatu daerah yang memiliki sumberdaya perikanan bernilai ekonomis seperti halnya rajungan diperlukan untuk mengetahui efisiensi dalam kegiatan perikanan tangkap. Penelitian dilaksanakan pada lokasi pendaratan rajungan di pesisir timur Lampung, meliputi 2 Kabupaten yaitu Kabupaten Lampung Timur (lokasi Labuhan Maringgai / LM dan Kuala Penet / KP) dan Kabupaten Tulang Bawang (lokasi Way Seputih / SPT, Sungai Burung / SB dan Kuala Teladas / KT) (Gambar 1). Penelitian dilaksanakan pada bulan April 2017.

\section{Karakteristik Penangkapan Rajungan}

Karakteristik penangkapan rajungan di pesisir timur Lampung menggunakan analisis deskriptif dengan data hasil observasi langsung serta didukung oleh penelitian terdahulu. Dalam penelitian ini menggunakan stratifikasi daerah penangkapan rajungan berdasarkan jarak dari pelabuhan ke daerah tangkapan. Diantaranya stratifikasi 1 (S1) dengan dengan jarak $\leq 5$ mil dan stratifikasi 2 (S2) dengan jarak $>5$ mil. Habitat pemijahan rajungan menurut Agus et al. (2016) berada di perairan yang memiliki pengaruh estuari kuat serta suhu perairan yang lebih hangat dan salinitas lebih rendah, sedangkan daerah rekruitmen berada di perairan terpengaruh oseanik yang lebih kuat.

Kondisi lingkungan perairan menurut Setyawan \& Wirasatriya (2017) dapat mempengaruhi pola kehidupan rajungan ( $P$. pelagicus). Daerah penangkapan rajungan (fishing ground) dapat diprediksi dengan mengetahui parameter oseanografi seperti kedalaman, arus, salinitas dan suhu perairan yang mempengaruhinya. Menurut Ernawati (2013), intensitas cahaya optimum yang masuk ke perairan 
lebih dalam hingga dasar perairan akan memudahkan rajungan untuk mencari makan karena rajungan umumnya bersifat nokturnal, aktif pada malam hari terutama untuk mencari makan.

Analisis deskriptif dari karakteristik aktivitas penangkapan dari 5 lokasi pendaratan rajungan, menunjukkan hasil perbandingan karakteristik penangkapan rajungan berdasarkan jumlah trip dan jumlah armada penangkapan (Tabel 1). Labuhan Maringgai memiliki jumlah kapal yang lebih banyak dibanding dengan jumlah kapal di lokasi lain (Yayasan PUTER Indonesia, 2017). Dimaksud jumlah trip penangkapan rajungan adalah jumlah hari melaut yang dilakukan nelayan untuk menangkap rajungan. Kisaran jumlah melaut di timur Lampung antara 16-27 trip/ bulan. Jumlah kapal dan hari melaut di lokasi penelitian dikemukakan pada Tabel 1. Operasi penangkapan rajungan didominasi oleh nelayan yang menangkap secara harian (one day trip). Nelayan yang tidak melaut lebih banyak disebabkan karena cuaca yang buruk, perbaikan jaring/kapal, acara keagamaan atau untuk beristirahat. Nelayan di lokasi penelitian ini memiliki pekerjaan utama sebagai nelayan rajungan. Aktivitas penangkapan rajungan dalam 1 kapal biasa dilakukan antara 2-4 orang.

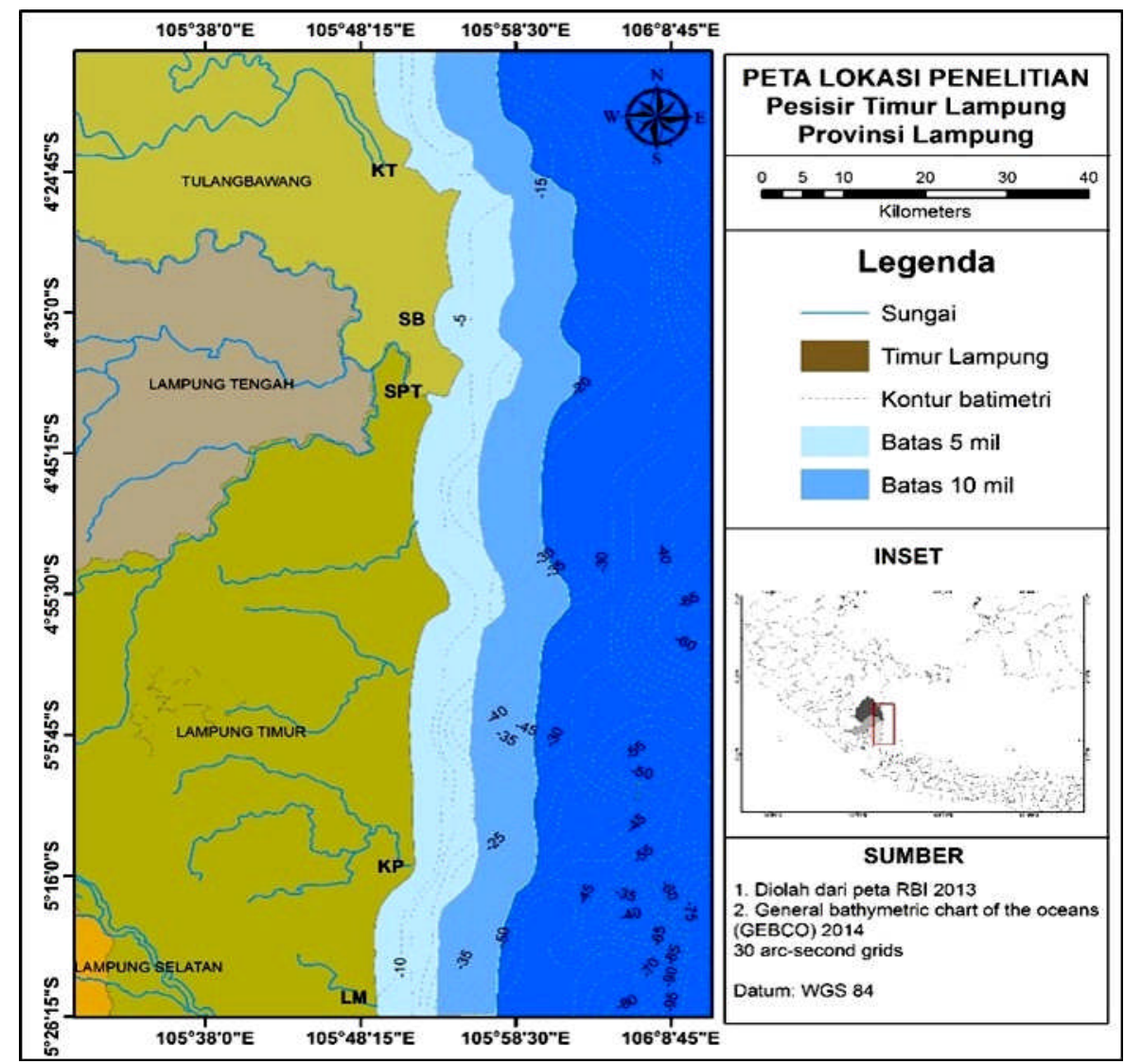

Gambar 1. Lokasi penelitian rajungan di timur Lampung.

Figure 1. Research location of blue swimming crab in the eastern of Lampung.

Tabel 1. Jumlah hari melaut dan jumlah kapal nelayan rajungan di pesisir timur Lampung Table1. The number of fishing effort and the number of fishing boats in the east coast of Lampung

\begin{tabular}{lccccc}
\hline & \multicolumn{5}{c}{ Lokasi/Location } \\
\cline { 2 - 6 } & LM & KP & SPT & SB & KT \\
\hline Jumlah kapal(unit) $^{*}$ & 250 & 60 & 40 & 50 & 50 \\
Jumlah hari melaut(hari) $^{20}$ & 16 & 27 & 20 & 20 \\
\hline
\end{tabular}

Sumber:

Yayasan PUTER Indonesia (1917)

Keterangan/Remarks : $\mathrm{LM}=$ Labuhan Maringgai, $\mathrm{KP}=$ Kuala Penet, $\mathrm{SPT}=$ Seputih, $\mathrm{SB}=$ Sungai Burung, $\mathrm{KT}=$ Kuala Teladas 
Tingginya jumlah aktivitas penangkapan rajungan diduga karena adanya permintaan pasar dan harga jual yang tinggi. Tingginya jumlah kapal di lokasi pendaratan Labuhan Maringgai diduga akibat adanya peningkatan jumlah nelayan pendatang dan jumlah populasi nelayan pada lokasi pendaratan (Damora \& Nurdin, 2016; Damora, 2016). Penangkapan rajungan yang bersifat intensif tanpa didukung dengan upaya pengelolaan yang baik, akan berakibat menurunnya stok di alam. Sehingga pada akhirnya akan mempengaruhi keberlanjutan aktivitas penangkapan rajungan (Hamid, 2015). Eksploitasi rajungan di daerah pesisir Lampung Timur terjadi pada hampir seluruh habitat dan terjadi selama sepanjang tahun. Penurunan stok di alam ditandai dengan turunnya rata-rata bobot individu $(132,79 \pm 69,93 \mathrm{~g})$ dan semakin kecilnya rata-rata lebar karapas rajungan yang tertangkap $(121,27 \pm 18,85 \mathrm{~mm})$. Hal tersebut diduga karena adanya aktivitas penangkapan yang berlebih dan penurunan produksi stok yang dapat mengganggu keberlanjutan sumberdaya (Zairion et al., 2014). Penurunan stok rajungan di alam akan berpengaruh terhadap jumlah hasil tangkapan nelayan baik dari segi ukuran dan volume hasil tangkapan. Volume hasil tangkapan pada saat musim puncak lebih tinggi dibandingkan pada musim lainnya, namun tidak diimbangi dengan harga jual. Harga jual rajungan pada musim puncak lebih rendah dibandingkan dengan harga jual pada musim sedang dan paceklik (Tabel 2).

Tabel 2. Harga jual rata-rata rajungan di pesisir Timur Lampung

Table 2. The average selling price of blue swimming crab on the east coast of Lampung

\begin{tabular}{llll}
\hline \multirow{2}{*}{ Lokasi/Location } & \multicolumn{3}{c}{ Musim /Seasons } \\
\cline { 2 - 4 } & Puncak/High (Rp/Kg) & Sedang/Middle (Rp/Kg) & Paceklik/Low (Rp/Kg) \\
\hline LM & 10.000 & 33.667 & 50.267 \\
KP & 12.071 & 27.143 & 47.500 \\
SPT & 20.000 & 40.000 & 60.000 \\
SB & 15.000 & 35.000 & 55.000 \\
KT & 15.000 & 35.000 & 55.000 \\
\hline
\end{tabular}

Musim penangkapan rajungan di pesisir timur Lampung terbagi menjadi 3, yaitu musim puncak, musim sedang dan musim paceklik. Berdasarkan hasil wawancara kepada nelayan rajungan yang ada di pesisir timur Lampung, musim puncak berlangsung pada bulan November/Desember-awal bulan Maret, musim sedang berlangsung pada bulan Maret-Juni dan musim paceklik berlangsung pada bulan JuliNovember. Hal tersebut sedikit berbeda dengan pola musim penangkapan dari penelitian terdahulu oleh Zairion (2015) dengan data pola musim puncak berlangsung pada Desember/Januari-Maret/April, musim sedang berlangsung pada bulan April/Mei-Juni dan Oktober-November dan musim paceklik berlangsung pada bulan Juli/Agustus-September/ Oktober.

Musim penangkapan rajungan di Indonesia pada umumnya terjadi pada musim barat. Kecepatan arus pada musim barat memiliki nilai korelasi positif terhadap jumlah hasil tangkapan rajungan di perairan Teluk Lasongko dan Lampung Timur, dimana ketika kecepatan arus meningkat maka akan meningkat pula hasil tangkapan (Hamid, 2015; Zairion, 2015). Menurut Hamid (2015), selain kecepatan arus, variabel kualitas air berkorelasi nyata dengan jumlah tangkapan rajungan di Teluk Lasongko. Aktivitas penangkapan rajungan di pesisir timur Lampung berlangsung selama sepanjang tahun, tetapi pada saat musim paceklik sebagian nelayan beralih menjadi menangkap udang dengan alat tangkap trammel net atau menangkap ikan dengan jaring rampus (Zairion, 2015). Masih adanya nelayan yang tetap melakukan aktivitas penangkapan rajungan diduga karena harga yang lebih tinggi pada musim paceklik dibanding musim lainnya. Meskipun penghasilan yang didapatkan pada musim paceklik tidak sebesar yang diperoleh pada musim puncak.

Nilai produksi nelayan rajungan di pesisir timur Lampung berbeda secara spasial maupun temporal. Jumlah hasil tangkapan rajungan bervariasi menurut daerah dan musim (Zairion, 2015). Analisis hasil tangkapan per-upaya rajungan berdasarkan musim di masing-masing lokasi penelitian dapat dilihat pada Gambar 2.

Hasil tangkapan pada musim puncak pada stratifikasi 1 di Kuala Seputih dan Sungai Burung memiliki jumlah yang lebih tinggi dibandingkan dengan hasil tangkapan per-trip di lokasi lainnya. Hal tersebut diduga karena lokasi penangkapan nelayan rajungan di Seputih dan Sungai Burung tersebar dibeberapa lokasi penangkapan dan ukuran lebar karapas rajungan yang lebih besar dibandingkan dengan lokasi penangkapan di Labuhan Maringgai, Kuala Penet dan Kuala Teladas. Selain itu, populasi nelayan yang ada di Seputih dan Sungai Burung lebih sedikit dibandingkan dengan populasi nelayan di 3 lokasi lainnya. 


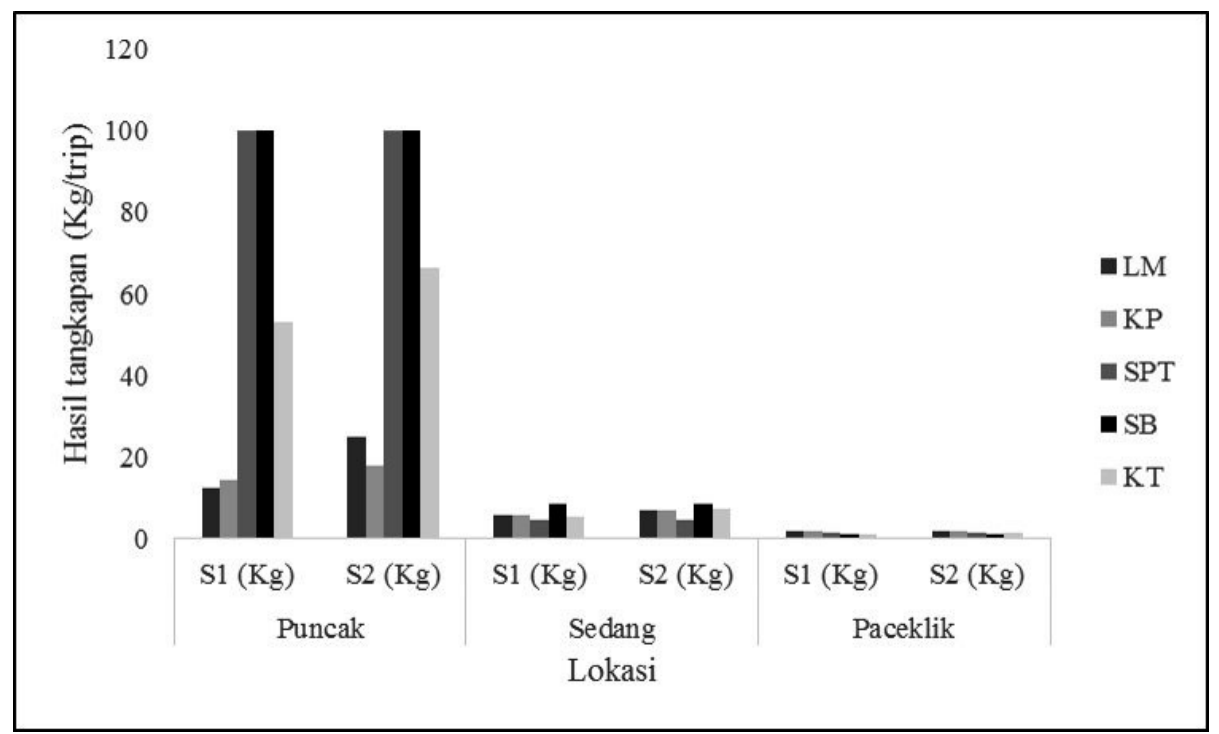

Gambar 2. Nilai produksi insidental di 2 strata lokasi penelitian.

Figure 2. Incidental production values in the 2 strata of the study site.

\section{Bioekonomi Spasial}

Model bioekonomi pada dasarnya digunakan untuk mengetahui cara terbaik dalam pengelolaan perikanan yang bersifat open acces (Zulbainarni, 2016). Bioekonomi spasial digunakan untuk kondisi sumberdaya ikan yang bersifat heterogen dalam distribusi spasial dan upaya tangkap (Anderson \& Seijo, 2010). Pada bioekonomi spasial, variabel upaya penangkapan dipengaruhi oleh hasil dari biaya berdasarkan ruang dan waktu pada seluruh daerah tangkapan (fishing ground) maupun pada daerah tangkapan tertentu. Bioekonomi mampu menggambarkan rentang yang sangat luas dari kondisi ekologi dan ekonomi (Sanchirico \& Wilen, 1998). Menurut Conrad \& Smith, (2012), tidak hanya dinamika spasial yang mengubah dinamika area individu, dinamika spasial juga dapat merubah secara menyeluruh meskipun tidak ada perubahan terhadap produktivitas ekonomi maupun biologi terhadap kondisi awal. Pengelolaan perikanan dalam studi kasus ini adalah pengelolaan perikanan rajungan secara spasial dengan keragaman kelimpahan yang berbeda pada setiap lokasi penangkapan yang sesuai dengan ruang dan waktu serta keterkaitan ekologi dan ekonomi pada suatu kerangka ekosistem (Seijo, 2007). Alokasi spasial dinamika dari intensitas perikanan rajungan diperoleh dari rumus berikut (Seijo et al., 1998):

$$
f_{k h m}(t)=S A E_{k h m}(t) \cdot D A Y S \cdot V_{h m}(t)
$$

Dimana $S A E_{k h m(t)}$ diperoleh dari :

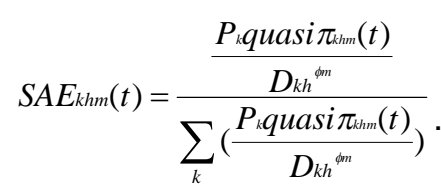

Keterangan:

$$
\begin{aligned}
& \mathrm{SAE}_{\mathrm{khm}}(\mathrm{t}) \quad \text { : alokasi upaya penangkapan secara } \\
& \text { spasial (trip) }
\end{aligned}
$$

Besarnya keuntungan jangka pendek nelayan rajungan adalah:

$$
\text { quasi } \pi k m h(t)=\operatorname{TRkhm}(t)-V C k h m(t)
$$

Keterangan:

$\mathrm{TR}_{\mathrm{khm}}(\mathrm{t})$ : penerimaan total yang diterima oleh kapal $m$ dari lokasi pendaratan $h$, dari hasil menangkap rajungan di daerah penangkapan $k(\mathrm{Rp})$.

$\mathrm{VC}_{\mathrm{khm}}(\mathrm{t})$ : biaya variabel yang dikeluarkan oleh kapal $m$ dari lokasi pendaratan $h$, dari hasil menangkap rajungan di daerah penangkapan $k(\mathrm{Rp})$.

Pendugaan biaya variabel (variabel cost) dihitung dengan rumus : 


$$
V C_{k h m}(t)=\omega q_{k} B_{k}(t)+\theta D_{k h}+O V C_{m}
$$

Keterangan:

Dkh : transfer cost yang didefinisikan sebagai fungsi dari jarak

u : biaya bahan bakar rata-rata per-km jarak yang ditempuh

wqkBk : nilai proporsi hasil tangkapan dengan keuntungan yang diperoleh

OVC : nilai biaya variabel lainnya (pemeliharaan)

Total keuntungan ekonomi secara keseluruhan yang diterima oleh kapal $m$ dari pelabuhan asal $h$ pada musim penangkapan tertentu, dihitung dengan menggunakan rumus :

$$
\pi_{k h m}(t+D T)=\pi_{k h m}(t)+\int_{t}^{t+D T}\left(T R_{k h m}(t)-T C_{k h m}(t)\right) d t . .
$$

Keterangan:

$\mathrm{TR}(\mathrm{t}) \quad$ : penerimaan kotor perikanan pada saat $t$ (Rp)

$\mathrm{TC}(t)$ : biaya penangkapan rajungan pada saat $t$ (Rp)

Total penerimaan (TR) dan total biaya (TC) didefinisikan sebagai:

$$
\begin{aligned}
& T R_{k h m}(t)=\left(q_{m} B_{k}(t) P_{t a r}+Y_{i n c} \cdot P_{i n c}\right) f_{k h m}(t) \\
& T C_{k h m}(t)=F C_{m} V_{h m}+V C_{k h m}(t) f_{k h m} \ldots \ldots \ldots \ldots . . .
\end{aligned}
$$

\section{Keterangan:}

$P_{\text {tar }} \quad$ : harga rata-rata rajungan $(\mathrm{Rp} / \mathrm{Kg})$

$P_{\text {inc }}^{\text {tar }}$ : harga rata-rata rajungan hasil tangkapan insidental $(\mathrm{Rp} / \mathrm{Kg})$

$Y_{\text {inc }}$ : hasil tangkapan insidental rata-rata per-trip (Kg)
$\mathrm{F}_{\mathrm{m}} \quad$ : upaya penangkapan kapal $\mathrm{m}$ yang berangkat dari pelabuhan $h$ dan menangkap ikan di daerah penangkapan $k$ (trip)

$\mathrm{Q}_{\mathrm{m}}$ : koefisien ketertangkapan (catchability coefficient) dari kapal $m$

$\mathrm{B}_{\mathrm{k}} \quad$ : nilai produksi yang ditangkap di daerah penangkapan $h(\mathrm{Kg})$

$\mathrm{F}_{\mathrm{cm}} \quad$ : daily fixed cost, termasuk pembayaran bunga untuk modal yang dipinjam, biaya administrasi dan oppurtunity cost of capital (OCC) untuk kapal $m(\mathrm{Rp})$

$\mathrm{V}_{\mathrm{hm}} \quad$ : jumlah kapal $m$ di pelabuhan $h$

$\mathrm{VC}_{\mathrm{kh}}$ : biaya variabel untuk kapal $m$ yang berangkat dari pelabuhan $h$ dan menangkap rajungan di daerah penangkapan $k(R p)$

Model bioekonomi spasial dikembangkan pada akhir tahun 1990 sebagai bentuk pentingnya lokasi dalam pengelolaan sumberdaya (Conrad \& Smith, 2012). Gambar 3 dan 4 menunjukkan perbedaan alokasi spasial dalam aktivitas penangkapan rajungan di pesisir timur Lampung. Menurut Damora (2016), perbedaan tersebut disebabkan karena adanya perbedaan jumlah hasil tangkapan dan besarnya jumlah peluang ketertangkapan pada setiap lokasi penangkapan. Alokasi spasial yang didapatkan merupakan rekomendasi daerah tangkapan dalam aktivitas penangkapan rajungan. Berdasarkan hasil analisis yang diperoleh, pada saat musim paceklik nelayan Labuhan Maringgai dan Kuala Teladas tidak direkomendasikan untuk melakukan aktivitas penangkapan di stratifikasi 1 . Tidak adanya data hasil analisis di Seputih, Sungai Burung dan Kuala Teladas pada stratifikasi 2 disebabkan karena nelayan Seputih dan Sungai Burung melakukan aktivitas penangkapan dengan jarak $\leq 5$ mil.

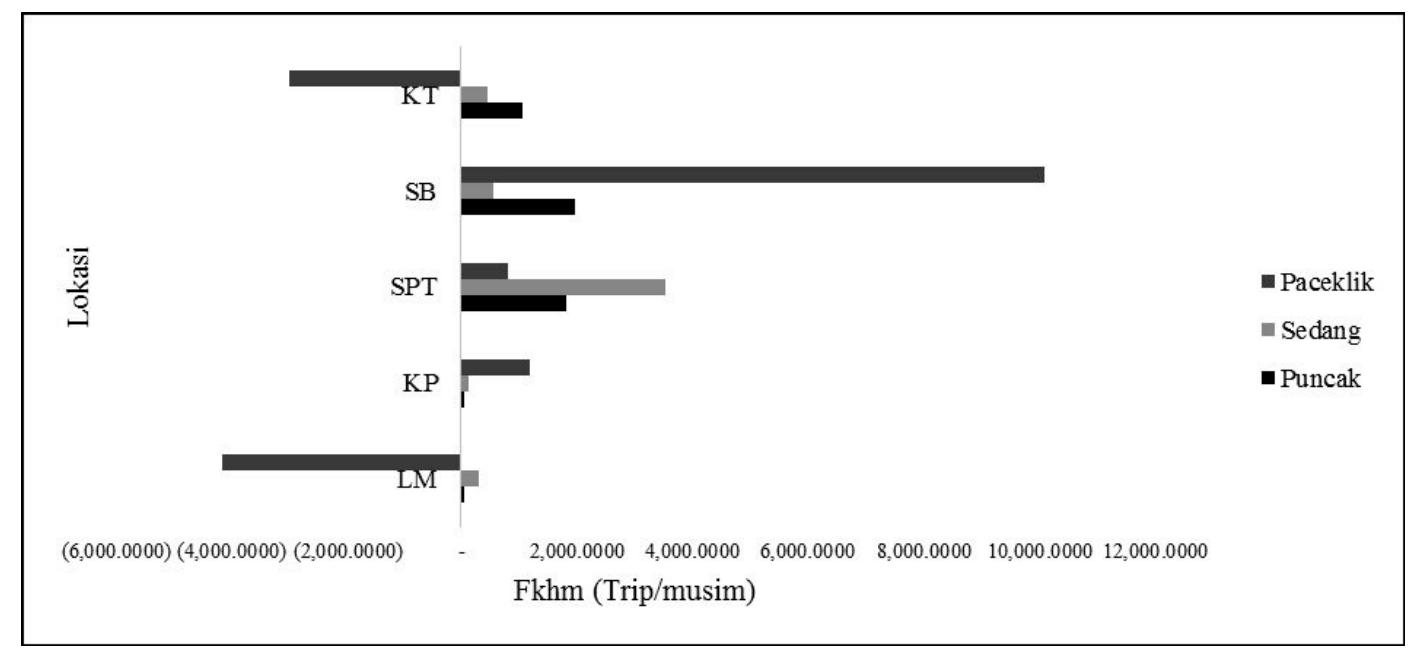

Gambar 3. Jumlah alokasi spasial di strata 1.

Figure 3. Amount of spatial allocation in level 1. 


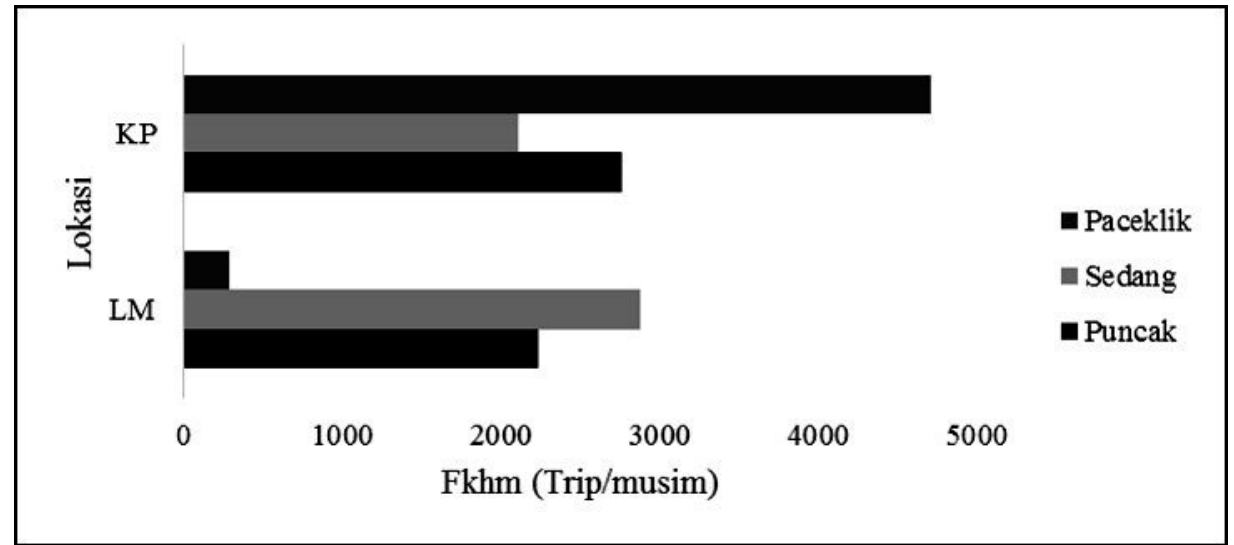

Gambar 4. Jumlah alokasi spasial di strata 2.

Figure 4. Amount of spatial allocation in level 2.

Keuntungan yang didapatkan dari aktivitas penangkapan pada stratifikasi 1 dan 2 disajikan pada Gambar 5. Keuntungan tertinggi diperoleh pada musim paceklik di stratifikasi 1 berada pada lokasi penangkapan Sungai Burung dengan nilai sebesar Rp. 403174 251.- dibandingkan dengan lokasi lainnya. Sedangkan kerugian didapat pada saat nelayan menangkap rajungan di musim paceklik pada stratifikasi 1 di Labuhan Maringgai dengan nilai Rp. 151732 875.-. Perbedaan nilai penerimaan tersebut diakibatkan karena adanya perbedaan harga jual rajungan pada setiap lokasi penelitian. Pada saat musim puncak, harga jual rajungan (per-kg) di Seputih (SPT) mencapai Rp. 20.000,-. Nilai ini lebih tinggi dibandingkan dengan harga jual rajungan di lokasi lainnya. Sedikitnya pendapatan yang diperoleh dari hasil melaut akan berlangsung hingga dicapai keuntungan normal. Pada saat terjadi peningkatan upaya penangkapan yang melebihi batas akan merugikan nelayan yang disebabkan karena biaya yang dikeluarkan lebih besar dibandingkan dengan penerimaan yang diperoleh (Zulbainarni, 2016).

Hasil tangkapan yang melimpah tidak sejatinya memberikan keuntungan yang tinggi kepada nelayan. Hal tersebut dipengaruhi pula oleh adanya harga jual hasil tangkapan kepada pengepul. Pada saat musim puncak, harga jual rajungan mengalami penurunan. Sedangkan pada saat musim sedang atau peralihan harga rajungan mulai meningkat, dan pada saat musim paceklik harga semakin tinggi. Keuntungan tertinggi diperoleh pada musim puncak, meskipun harga jual rajungan pada musim sedang dan paceklik lebih tinggi dibandingkan pada saat musim puncak (Gambar 5).

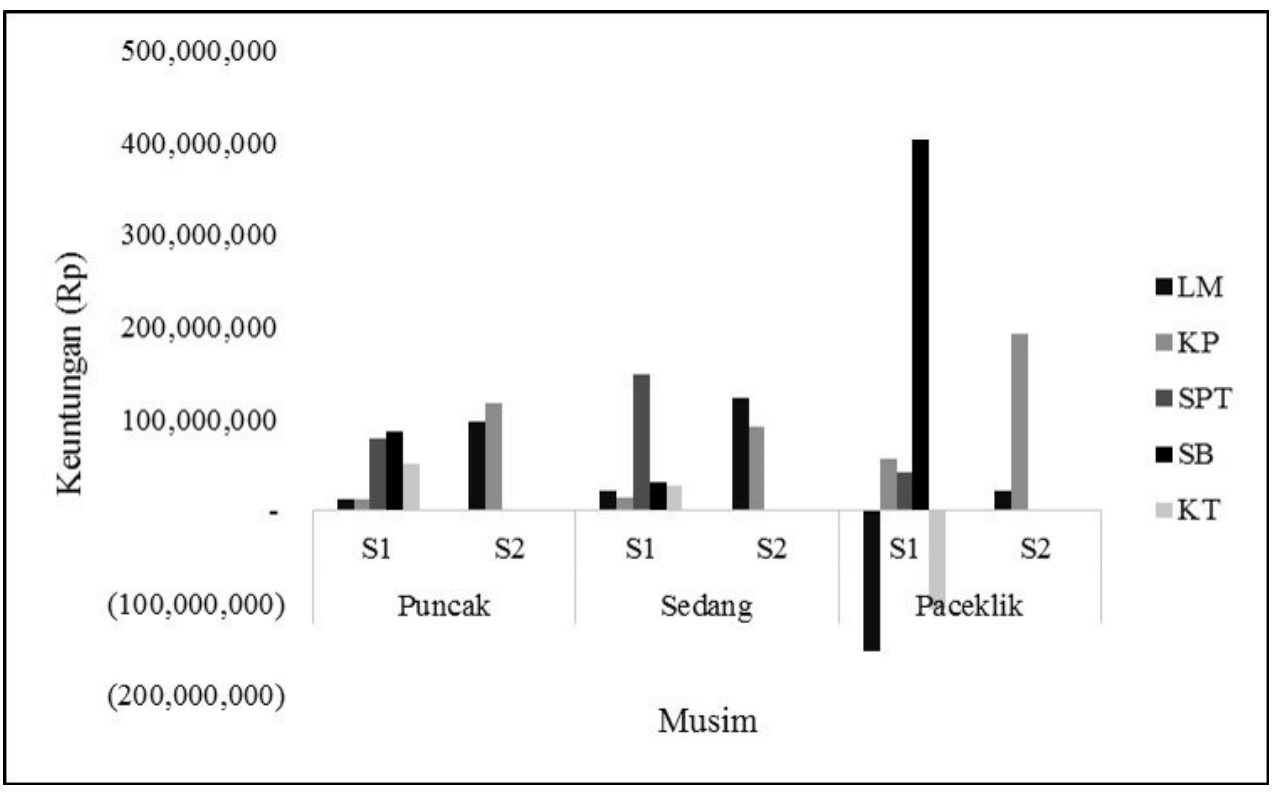

Gambar 5. Nilai keuntungan yang diperoleh berdasarkan musim dan daerah penangkapan rajungan.

Figure 5. The value of profits obtained based on the season and fishing area. 
Dinamika pada pengelolaan perikanan rajungan tidak terlepas dari kompleksitas ekosistem tropis yang menjadi salah satu ciri pada ekosistem tropis. Kompleksitas ekosistem tropis dimaksudkan pada pengelolaan rajungan yang bertujuan untuk memberikan manfaat sosial ekonomi yang optimal tidak dapat terlepas dari dinamika ekosistem rajungan itu sendiri (Budiarto et al., 2015). Menurut Kroetz \& Sanchirico, (2015), lingkungan, geografi, topografi dapat menyebabkan heterogenitas terhadap biaya yang dikeluarkan dan keuntungan yang diperoleh di setiap lokasi pemanfaatan. Berkurangnya nilai potensi lestari suatu sumberdaya di perairan pantai maka akan berdampak pada berkurangnya pendapatan nelayan (Triarso, 2012).

Faktor yang mempengaruhi analisis ekonomi dari sisi aspek ekonomi pada umumnya adalah aspek pasar (harga, biaya, suku bunga dan sebagainya) dan non pasar (nilai-nilai intrinsik non konsumtif), aspek preferensi konsumen dan produsen yang terlibat dalam aktivitas perikanan, dan aspek aktivitas ekonomi (Fauzi, 2010). Jika terjadi peningkatan pada aspek pasar seperti peningkatan biaya bahan bakar dan penurunan permintaan pasar, maka akan mengurai keuntungan ekonomi yang diperoleh. Salah satu aspek ekonomi yang diperlukan dalam kajian bioekonomi adalah aspek ekonomi itu sendiri. Pada saat harga jual meningkat, maka akan terjadi peningkatan jumlah penerimaan nelayan (Zulbainarni, 2016).

Analisis harga dari hasil penelitian ini menunjukan harga yang tidak konstan menurut musim dan lokasi pendaratan rajungan. Berdasarkan Tabel 2 terlihat perbedaan harga jual rajungan terhadap musim penangkapan dan lokasi pendaratan. Hal ini membuktikan bahwa semakin tinggi harga jual, maka pendapatan yang diperoleh nelayan akan meningkat. Tujuan akhir dalam pengelolaan perikanan adalah memberikan manfaat sosial ekonomi yang optimal bagi masyarakat yang tidak dapat dilepaskan dari dinamika ekosistem yang merupakan media hidup bagi sumberdaya tersebut (Adrianto, 2015).

Sumberdaya perikanan yang bersifat open access akan menyebabkan terjadinya penangkapan berlebih (over fishing) yang kemudian akan mengancam kelestarian sumberdaya tersebut (Susilo, 2010). Penangkapan rajungan berukuran kecil dan rajungan mengerami telur, daerah penangkapan yang tidak merata, dan kegiatan perikanan yang tidak ramah lingkungan akan menyebabkan terjadinya over fishing (Hamid et al., 2017). Pengelolaan sumberdaya perikanan secara spasial memerlukan pemahaman mengenai karakteristik spasial dari spesies yang dikaji dengan kelimpahan yang berbeda pada setiap lokasi (Seijo, 2007). Pada Gambar 3 dan 4 terlihat perbedaan alokasi spasial dari aktivitas penangkapan rajungan di perairan pesisir timur Lampung berdasarkan musim dan stratifikasi lokasi penangkapan.

\section{KESIMPULAN DAN REKOMENDASI}

Jumlah alokasi optimal tertinggi pada musim puncak di stratifikasi 1 adalah di Sungai Burung dengan jumlah 1974 trip/musim dan di stratifikasi 2 tertinggi di Kuala Penet dengan jumlah 2763 trip/ musim. Musim sedang di stratifikasi 1 adalah di Way Seputih dengan jumlah 3540 trip/musim dan stratifikasi 2 tertinggi di Labuhan Maringgai dengan jumlah 2883 trip/musim. Musim paceklik di stratifikasi 1 adalah di Sungai Burung dengan jumlah 10088 trip/ musim dan stratifikasi 2 di Kuala Penet dengan jumlah 4708 trip/musim. Jumlah alokasi trip optimal dapat digunakan sebagai acuan trip yang diperbolehkan pada aktivitas penangkapan rajungan oleh nelayan di perairan pesisir timur Lampung. Penetapan alokasi trip optimal disesuaikan dengan lokasi penangkapan berdasarkan stratifikasi dan musim penangkapan.

\section{PERSANTUNAN}

Tulisan ini merupakan bagian dari kerjasama penelitian antara Yayasan Bina Usaha Lingkungan (YBUL) dengan Fakultas Perikanan dan IImu Kelautan IPB pada tahun 2017.

\section{DAFTAR PUSTAKA}

Adam, Jaya, I., \& Sondita M.F.A. (2006). Model bioekonomi perairan pantai (in-shore) dan lepas pantai (off-shore) untuk pengelolaan perikanan rajungan (Portunus pelagicus) di perairan Selat Makassar. Jurnal IImu-ilmu Perairan dan Perikanan Indonesia. 13(1): 33-43.

Adrianto, L. (2015). Pengelolaan perikanan dengan pendekatan ekosistem-integrasi platform pengelolaan kawasan konservasi perairan dan perikanan. Didalam: Tata Kelola Kawasan Konservasi Perairan untuk Perikanan Berkelanjutan di Indonesia. IPB Press: Bogor (ID).

Agus, S.B., Zulbainarni, N., Sunuddin, A., \& Subarno, T. (2016). Distribusi spasial rajungan (Portunus pelagicus) pada musim timur di perairan Pulau Lancang, Kepulauan Seribu. Jurnal Ilmu Pertanian Indonesia (JIPI). 21(3): 209-218. DOI: https:// doi.org/10.18343/jipi.21.3.209 
Anderson, L.G., \& Seijo, J.C. (2010). Bioeconomics of fisheries management (p. 305). USA. Blackwell publishing.

Budiarto, A., Adrianto, L., \& Kamal, M. (2015). Status pengelolaan perikanan rajungan (Portunus pelagicusd) dengan pendekatan ekosistem di Laut Jawa (WPPNRI 712). Jurnal Kebijakan Perikanan Indonesia (JKPI). 7(1): 9-24. DOI: http://dx.doi.org/ 10.15578/jkpi.7.1.2015.9-24

Conrad, J.M., \& Smith, M.D. (2012). Non spatial and spatial models in bioeconomics. Journal Natural Resources Modeling. 25(1). 52-92. DOI: https:// doi.org/10.1111/j.1939-7445.2011.00102.x

Damora, A. (2016). Optimasi pemanfaatan sumber daya lobster pasir (Panulirus homarus) dalam kerangka ekologi-ekonomi di Kabupaten Gunung Kidul dan sekitarnya [tesis]. Sekolah Pascasarjana. Bogor (ID): Institut Pertanian Bogor.

Damora, A., Nurdin, E. (2016). Beberapa aspek biologi rajungan (Portunus pelagicus) di perairan Labuhan Maringgai, Lampung Timur. BAWAL. 8(1): 13-20. DOI: http://dx.doi.org/10.15578/ bawal.8.1.2016.13-20

Ernawati, T. (2013). Dinamika populasi dan pengkajian stok sumberdaya rajungan (Portunus pelagicus Linnaeus) di perairan Kabupaten Pati dan sekitarnya [tesis]. Sekolah Pascasarjana. Bogor (ID): Institut Pertanian Bogor.

Fauzi, A. (2010). Ekonomi Perikana (223 hlm). Gramedia Pustaka Utama. Jakarta (ID).

Hamid, A. (2015). Habitat, biologi reproduksi dan dinamika populasi rajungan (Portunus pelagicus Linnaeus 1758) sebagai dasar pengelolaan di Teluk Lasongko, Sulawesi Tenggara [disertasi]. Sekolah Pascasarjana. Institut Pertanian Bogor. Bogor(ID).

Hamid, A., Wardiatno, Y., Batu, D.T.F.L., \& Riani, E. (2017). Pengelolaan rajungan (Portunus pelagicus) yang berkelanjutan berdasarkan aspek bioekologi di Teluk Lasongko, Sulawesi Tenggara. J.Kebijak.Perik.Ind, 9(1): 41-50. DOI: http:// dx.doi.org/10.15578/jkpi.9.1.2017.41-50

[KKP] Kementerian Kelautan dan Perikanan. (2018). Kinerja Ekspor Produk Perikanan Indonesia Tahun 2018. Ditjen Penguatan Daya Saing Produk Kelautan dan Perikanan. KKP. https://kkp.go.id/ djpdspkp/artikel/7947-kinerja-ekspor-produkperikanan-indonesia-tahun-2018
Kroetz, K., \& Sanchirico, J.N. (2015). The bioeconomics of spatial-dynamic systems in natural resources management. Annual Review of Resources Economics. 7,189-207. DOI: https:// doi.org/10.1146/annurev-resource-083110-120047

Kurnia, R., Boer, M., Zairion. (2014). Biologi populasi rajungan (Portunus pelagicus) dan karakteristik lingkungan habitat esensialnya sebagai upaya awal perlindungan di Lampung Timur. Jurnal IImu Pertanian Indonesia (JIPI). 19(1): 22-28.

Sanchirico, J.N., \& Wilen, J.E. (1998). Bioeconomics of spatial exploitation in patchy environment. Journal of Environment Economics and Management. 37(2), 129-150. DOI: https://doi.org/ 10.1006/jeem.1998.1060

Seijo, J.C., Defeo, O., Salas, S. (1998). Fisheries bioeconomics: Theory, modelling and management. FAO Fisheries Technical Paper. Rome (IT). FAO. 108p.

Seijo, J.C. (2007). Spatial bioeconomic dynamics of marine fisheries. Fisheries and Aquaculture Vol V. Encyclopedia of Life Support Systems (EOLSS). Universidad Marista de Merida, Mexico.

Setiyowati, D. (2016). Kajian stok rajungan (Portunus pelagicus) di perairan Laut Jawa, Kabupaten Jepara. Jurnal DISPROTEK. 7(1): 84-97. DOI: https://doi.org/10.34001/jdpt.v7i1.363

Setyawan, H.A., Wirasatriya, A. (2017). Hubungan antara daerah penangkapan rajungan (Portunus pelagicus) dengan parameter oseanografi di perairan Tegal Jawa Tengah. Di dalam: Wirasatriya A, Suryanti, Kurohman F, Teguh W, Nirwani, Ayu R, Dian A, Permata D, Hartati R, Helmi M (editor). Aplikasi IPTEK Perikanan dan Kelautan dalam Pengelolaan Mitigasi Bencana dan Degradasi Wilayah Pesisir, Laut dan Pulau-Pulau Kecil. Seminar Nasional Hasil Penelitian Perikanan dan Kelautan ke-Vl;2016 November 12. Semarang(ID). Fakultas Perikanan dan Ilmu Kelautan. Universitas Diponegoro. 67-81.

Supriani, E. (2007). Kajian ekonomi sumberdaya perikanan di perairan pemangkat Kabupaten Sambas [tesis]. Sekolah Pascasarjana. Bogor (ID): Institut Pertanian Bogor.

Susilo, H. (2010). Analisis bioekonomi pada pemanaatan sumberdaya ikan pelagis besar di perairan Bontang. EPP. 7(1): 25-30. 
Triarso, I. (2012). Potensi dan peluang pengembangan usaha perikanan tangkap di Pantura Jawa Tengah. Jurnal Saintek Perikanan. 8(1). DOI : https:// doi.org/10.14710/ijfst.8.1.65-73

Yayasan PUTER Indonesia. 2017. Karakteristik Perikanan Rajungan Timur Lampung: Laporan Pelaksanaan Survey. (Tidak diterbitkan)

Zairion, Boer, M., Wardiatno, Y., \& Fahrudin, A. (2014). Komposisi dan ukuran rajungan (Portunus pelagicus) yang tertangkap pada beberapa stratifikasi batimetri di perairan Lampung Timur. J.Lit.Perikan.Ind, 20(4), 199-206. DOI: http:// dx.doi.org/10.15578/jppi.20.4.2014.199-206
Zairion. (2015). Pengelolaan berkelanjutan perikanan rajungan (Portunus pelagicus) di Lampung Timur [disertasi]. Sekolah Pascasarjana. Bogor (ID): Institut Pertanian Bogor.

Zulbainarni, N. (2016). Teori dan Praktik Pemodelan Bioekonomi dalam Pengelolaan Perikanan Tangkap (310 hlm). IPB Press. Bogor (ID). 